\title{
Pengaruh Reduksi Pupuk NPK dengan Pembenaman Jerami, Aplikasi Pupuk Organik Dan Hayati terhadap Ketersediaan Hara, Populasi Mikroba, dan Hasil Padi Sawah di Indramayu
}

\author{
The Effect of Reduces the NPK Fertilizer with Incorporated Straw, Application Organic and \\ Biofertilizer towards Nutrient Availability, Microbe Population, and Rice Production at Indramayu \\ Elfa Najata dan Sugiyanta* \\ Departemen Agronomi dan Hortikultura, Fakultas Pertanian, Institut Pertanian Bogor \\ (Bogor Agricultural University), Jl. Meranti, Kampus IPB Darmaga, Bogor 16680, Indonesia \\ Telp.\& Faks. 62-251-8629353 e-mail agronipb@indo.net.id \\ *Penulis Korespondensi : mr_sugiyanta@yahoo.co.id
}

Disetujui : 14 November 2015 / Published online 12 Desember 2015

\begin{abstract}
This research aims to study availability condition nutrient and soil microbe population in paddy (Oryza sativa L.) within corporated straw, application organic and biofertilizer to reduce dose NPK at Indramayu, West Java. The experiment was conducted in Sendang village, Karang Ampel district, Indramayu, West Java, from november 2010 to march 2011. This research used completely randomized design group with 13 treatments and 3 aplication, that is P1: 1 dose NPK, P2: straw +1 dose NPK, P3: without fertilizer and without straw, P4: straw + 0.5 dose NPK, P5: straw + 0.5 dose NPK + biofertilizer 1, P6: straw + 0.5 dose NPK + biofertilizer $1+$ dekomposer, P7: straw + 0.5 dose NPK + biofertilizer $1+$ granule organic fertilizer $(P O G)$, P8: straw +0.5 dose NPK + POG + liquid organic fertilizer $(P O C)+$ dekomposer, P9: straw + 0.5 dose NPK + biofertilizer $1+P O G+P O C+$ dekomposer, P10: straw + 0.5 dose NPK +1 biofertilizer 2, P11: without straw +0.5 dose NPK +1 dose biofertilizer 2, P12: without straw +0.5 dose NPK +0.5 biofertilizer 2, P13: straw +0.5 dose NPK +0.5 dose biofertilizer 2 . The result showed that treatment incorporated straw, application organic and biofertilizer, and 0.5 dose NPK give result availability nutrient and rice production not different with treatment one dose NPK and in general increase mikrobe population (Azospirillium sp.,Azotobater sp. and Thiobacillus sp.).
\end{abstract}

Keywords: biofertilizer, incorporated straw, nutrient availability, organic fertilizer, soil microbe population

\begin{abstract}
ABSTRAK
Penelitian ini bertujuan mempelajari ketersediaan unsur hara dan populasi mikroba tanah dengan pembenaman jerami dan aplikasi pupuk organik dan pupuk hayati untuk mereduksi penggunaan dosis pupuk NPK di Indramayu Jawa Barat. Percobaan ini dilaksanakan di Desa Sendang Karang Ampel, Indramayu, Jawa Barat, dari bulan November 2010 - Maret 2011. Penelitian menggunakan Rancangan Acak Lenkap Teracak dengan 13 kombinasi perlakuan yang diulang 3 kali, Perlakuan yang dilakuakan yaitu: P1 (1 dosis NPK), P2 (jerami +1 dosis NPK), P3 (tanpa pupuk), P4 (jerami + 0.5 dosis NPK), P5 (jerami + 0.5 dosis NPK + PH 1), P6 (jerami +0.5 dosis NPK + PH $1+$ Dek $), P 7($ jerami +0.5 dosis NPK + PH $1+$ $P O G), P 8($ jerami +0.5 dosis NPK + POG + POC + Dek), P9 (jerami +0.5 dosis NPK + PH $1+P O G+$ $P O C+$ Dek.), $P 10$ (jerami +0.5 dosis NPK + PH 2), P11 (0.5 dosis NPK + PH 2), P12 (0.5 dosis NPK 0.5 +0.5 dosis PH 2), P13 (jerami +0.5 dosis NPK +0.5 dosis PH 2). Hasil menunjukkan perlakuan pembenaman jerami dengan pemberian pupuk hayati dan atau pupuk organik dan dosis 0,5 NPK memberikan hasil ketersediaan nutrisi dan produksi padi tidak berbeda dengan pemberian dosis satu NPK dan peningkatan populasi umum mikrobe (Azospirillium sp., Azotobater sp., dan Thiobacillus sp. ).
\end{abstract}

Kata kunci: ketersedian nutrisi, pembenaman jerami, populasi mikroba tanah, pupuk hayati, pupuk organik 


\section{PENDAHULUAN}

Tanaman padi (Oryza sativa L.) merupakan komoditas yang sangat penting di Indonesia. Padi merupakan penghasil beras yang menjadi makanan pokok hampir sebagian besar rakyat Indonesia. Peningkatan produksi beras saat ini belum mampu mengimbangi peningkatan tingkat konsumsi penduduk. Berdasarkan data Badan Pusat Statistik tahun 2010, pada tahun 2009 produksi padi Indonesia sebesar 64398890 ton dengan luas panen 12883576 ha dan produktivitas rata-rata $49.99\left(\mathrm{ku} \mathrm{ha}^{-1}\right)$.

Pengembangan varietas unggul, berumur pendek, produktivitas tinggi, dan responsif terhadap pemupukan telah menempatkan pupuk anorganik sebagai faktor penting dalam upaya peningkatan produksi padi di Indonesia. Penggunaan pupuk anorganik oleh para petani umumnya sudah menyimpang dari rekomendasi umum. Dampaknya, laju peningkatan padi tidak selaras dengan laju penggunaan pupuk sehingga muncul pelandaian produktivitas padi yang mencerminkan penurunan efisiensi penggunaan pupuk dan gangguan terhadap kesehatan tanah. Hal tersebut merupakan suatu petunjuk bahwa efisiensi pemupukan telah menurun, salah satu sebabnya adalah kurangnya perawatan dan pelestarian sumber daya tanah sehingga kesuburannya menurun baik dari segi kimia, fisika maupun biologi tanah. Bahan organik merupakan subtrat alami untuk mikroba tanah dan secara tidak langsung memberikan nutrisi bagi tanaman melalui kegiatan mikroba tanah. Mikroba penyubur tanah hidup berasosiasi dengan akar tanaman, meningkatkan ketersediaan hara, memacu pertumbuhan dan melindungi tanaman melawan patogen melalui senyawa fitohormon, antimikroba, toksin dan enzim yang dihasilkannya (Saraswati et al., 2004).

Upaya untuk meningkatkan produktivitas lahan secara berkelanjutan diperlukan terobosan yang mengarah pada efisiensi usahatani dengan memanfaatkan sumberdaya lokal. Las et al. (1999) menyatakan bahwa dalam meningkatkan produksi padi perlu dilakukan pelestarian lingkungan produksi, termasuk mempertahankan kandungan bahan organik tanah dengan memanfaatkan jerami padi. Jerami padi sebagai salah satu bahan pembenah organik tersedia melimpah di kawasan sawah. Pemberian jerami 5 ton/ha dapat meningkatkan hasil gabah padi sawah tadah hujan setara dengan pemupukan 30 kg N ha ${ }^{-1}$ (Basyir dan Suyamto, 1996). Berdasarkan uraian di atas, maka dilakukan kajian untuk melihat pengaruh pembenaman jerami, pupuk hayati, pupuk organik dan reduksi penggunaan pupuk NPK terhadap ketersediaan hara dan mikroba tanah pada padi sawah.

Penelitian ini bertujuan untuk mempelajari ketersediaan unsur hara dan populasi mikroba tanah dengan pembenaman jerami dan aplikasi pupuk organik dan pupuk hayati untuk mereduksi penggunaan dosis pupuk NPK.

\section{BAHAN DAN METODE}

Percobaan ini dilaksanakan di Desa Sendang Karang Ampel, Indramayu, Jawa Barat, dari bulan November 2010 - Maret 2011. Analisis tanah dilakukan di Laboratorium SEAMEO BIOTROP, Bogor. Analisis mikroba dilakukan di Laboratorium Biologi dan Kesehatan Tanah, Balai Penelitian Tanah, Bogor. Pengamatan biomassa dilakukan di Laboratorium Produksi, Departemen Agronomi dan Hortikultura, Fakultas Pertanian, IPB.

Bahan yang digunakan dalam penelitian ini antara lain benih padi varietas Ciherang, dekomposer (Dek), pupuk NPK, pupuk organik cair (POC), pupuk organik granul (POG), jerami padi sawah, pupuk hayati (PH 1) jenis 1 dan pupuk hayati jenis 2 ( $\mathrm{PH} 2$ ). Alat yang digunakan dalam percobaan ini adalah seperangkat alat budidaya, meteran, timbangan digital, oven, dan bagan warna daun.

Rancangan percobaan yang digunakan adalah Rancangan Kelompok Lengkap Teracak (RKLT) dengan satu faktor dan tiga ulangan. Dalam perlakuan terdapat 13 kombinasi perlakuan yang diulang tiga kali sehingga percobaan terdiri dari 39 satuan percobaan. Satuan percobaan berukuran $12 \mathrm{~m}$ x $7.5 \mathrm{~m}\left(90 \mathrm{~m}^{2}\right)$. Apabila terdapat perbedan yang nyata antar perlakuan, maka dilanjutkan dengan uji lanjut dunnet pada taraf $\alpha=5 \%$. Hasil data pertumbuhan dan produksi dianalisis menggunakan uji $\mathrm{F}$ dan bila nyata di uji lanjut menggunakan uji Dunnet taraf $5 \%$. Hasil analisis tanah diuji menggunakan uji-t ( $t$-student) pada taraf $\alpha=5 \%$

Perlakuan yang dilakuakan yaitu: P1 (1 dosis NPK), P2 (jerami +1 dosis NPK), P3 (tanpa pupuk), $\mathrm{P} 4$ (jerami +0.5 dosis NPK), P5 (jerami + 0.5 dosis NPK + PH 1), P6 (jerami +0.5 dosis $\mathrm{NPK}+\mathrm{PH} 1+$ Dek), $\mathrm{P} 7$ (jerami +0.5 dosis NPK + $\mathrm{PH} 1+\mathrm{POG}), \mathrm{P} 8$ (jerami +0.5 dosis $\mathrm{NPK}+\mathrm{POG}$ $+\mathrm{POC}+$ Dek $), \mathrm{P} 9$ (jerami +0.5 dosis NPK + PH 1 $+\mathrm{POG}+\mathrm{POC}+$ Dek.), P10 (jerami +0.5 dosis $\mathrm{NPK}+\mathrm{PH} 2), \mathrm{P} 11$ (0.5 dosis NPK + PH 2), P12 ( 0.5 dosis NPK $0.5+0.5$ dosis PH 2$), \mathrm{P} 13$ (jerami +0.5 dosis NPK + 0.5 dosis PH 2).

Pengolahan tanah dilakukan dua minggu sebelum penanaman. Petakan percobaan dibuat pematang yang tinggi. Setiap petak mempunyai 
saluran masuk dan keluar masing-masing. Penanaman dilakukan pada bibit berumur 14 hari setelah semai, penyulaman dilakukan pada 1-3 minggu setelah tanam (MST) dengan umur bibit yang sama. Pemupukan dilakukan sesuai dosis masing-masing percobaan. Pupuk organik granul (POG) dengan dosis 1 ton $\mathrm{ha}^{-1}$. Dekomposer diaplikasikan dengan menggunakan knapsack sprayer dua minggu sebelum tanam. Pupuk hayati jenis $1\left(21 \mathrm{ha}^{-1}\right)$ diaplikasikan satu minggu sebelum tanam, 1 MST, 3 MST dan 5 MST. Pupuk organik cair dan pupuk hayati jenis $2\left(21 \mathrm{ha}^{-1}\right)$ diaplikasikan dengan menggunakan knapsack sprayer pada 1 MST, 3 MST, 5 MST, dan 7 MST. Pupuk NPK (400 kg ha ${ }^{-1}$ ) pada 1 MST dilakukan dengan cara ditebar pada tiap petakan sesuai dosis pada tiap perlakuan. Pembenaman jerami dilakukan saat pengolahan tanah. Pengendalian hama dan penyakit dilakukan jika benar-benar diperlukan. Pemanenan dilakukan apabila gabah telah menguning 90-95\% dan dipanen dengan cara potong atas.

Peubah yang diamati meliputi: tingkat keasaman tanah, analisis kandungan C-organik, hara $\mathrm{N}, \mathrm{P}$, dan $\mathrm{K}$ dalam tanah yang tersedia dalam tanah, analisis kandungan hara $\mathrm{N}, \mathrm{P}$, dan $\mathrm{K}$ pada jerami dan gabah saat panen, analisis populasi mikroba Azotobakter sp., Azosporillium sp., dan Thiobacillius sp., Pengamatan vegetatif dari 3 MST sampai 7 MST (tinggi tanaman, jumlah anakan, tingkat hijau daun), Biomassa pada saat 8 MST, dan Produktivitas padi sawah baik gabah basah maupun gabah kering yang diamati per tanaman maupun per ubinan.

\section{HASIL DAN PEMBAHASAN}

\section{Analisis Kandungan Hara}

Berdasarkan hasil analisis unsur hara sebelum percobaan diketahui bahwa $\mathrm{pH}$ tanah tergolong agak masam (5.94), kandungan Corganik tanah rendah $(1.93 \%)$, hara $\mathrm{N}$ tanah rendah $(0.18 \%)$, hara $\mathrm{P}$ tanah rendah $(5.75 \mathrm{ppm})$ dan hara $\mathrm{K}$ tanah sangat rendah $(1.21 \mathrm{mg} / 100 \mathrm{~g})$. Berdasarkan hasil analisis tanah tersebut, status kesuburan tanah tergolong rendah. Secara rinci hasil analisis tanah disajikan pada tabel 1 .

Tabel 1. Hasil analisis kandungan hara tanah

\begin{tabular}{llclcc}
\hline \multicolumn{1}{c}{ Perlakuan } & $\mathrm{pH}$ & C-organik (\%) & $\mathrm{N}(\%)$ & $\mathrm{P}(\mathrm{ppm})$ & $\mathrm{K}(\mathrm{mg} / 100 \mathrm{~g})$ \\
\hline Awal & 5.94 & 1.93 & 0.18 & 5.75 & 1.21 \\
1 dosis NPK & 4.7 & 2.39 & 0.14 & 3.5 & 0.61 \\
J + 1 dosis NPK & 4.7 & 2.52 & 0.16 & 4.1 & 0.76 \\
Tanpa Pupuk & 4.6 & 2.64 & 0.15 & 6.4 & 0.79 \\
J + 0.5 dosis NPK & 4.6 & 2.60 & 0.17 & 6.2 & 0.81 \\
J + 0.5 dosis NPK + PH1 & 4.7 & 2.47 & 0.15 & 3.9 & 0.64 \\
J + 0.5 dosis NPK +PH1 + Dek & 4.8 & 2.60 & 0.18 & 4.4 & 0.69 \\
J + 0.5 dosis NPK + PH1 + & 4.7 & 2.88 & 0.17 & 5.4 & 0.74 \\
POG & & & & & \\
J + 0.5 dosis NPK +Dek+ POG & 4.8 & 2.76 & 0.17 & 6.2 & 0.76 \\
+ POC & & & & & \\
J + 0.5dosis NPK + Dek + & 4.7 & 2.42 & 0.16 & 6.6 & 0.79 \\
POG + POC +PH1 & & & & & \\
J + 0.5 dosis NPK + PH 2 & 4.8 & 2.60 & 0.14 & 3.7 & 0.59 \\
0.5 dosis NPK + PH 2 & 4.8 & 2.52 & 0.15 & 4.6 & 0.64 \\
0.5 dosis NPK + 0.5 dosis PH2 & 4.7 & 2.56 & 0.17 & 7.1 & 0.67 \\
J + 0.5 dosis NPK + 0.5 dosis & 4.8 & 2.47 & 0.16 & 6.7 & 0.68 \\
PH 2 & & & & & \\
P value & $0.000^{*}$ & $0.000^{*}$ & $0.001^{*}$ & 0.329 & $0.000^{*}$ \\
\hline Ke & & & &
\end{tabular}

Keterangan: TJ = Tanpa jerami ; $\mathrm{J}=$ Jerami ; ${ }^{*}$ : berbeda nyata pada uji t-student taraf $5 \%$

Berdasarkan hasil analisis statistik (uji $t$ student), pelakuan yang diaplikasikan nyata menurunkan nilai $\mathrm{pH}$, hara $\mathrm{N}$, dan hara $\mathrm{K}$, serta menaikan kandungan C-organik tanah. Nilai $\mathrm{pH}$ diakhir percobaan menunjukkan nilai rata-rata 4.7 satuan. Peningkatan C-organik tertinggi terlihat pada perlakuan Jerami +0.5 dosis NPK + PH $1+$ POG. Peningkatan C-organik diduga karena penambahan jerami kedalam tanah. Widati et al. (2000) menyatakan pemberian jerami dapat meningkatkan kadar C-organik, $\mathrm{K}$ tanah, dan KTK tanah berturut-turut sebesar $13.2 \%, 28.6 \%$, dan $153 \%$.

Kandungan unsur hara $\mathrm{N}$ dalam tanah diakhir percobaan menunjukkan bahwa semua perlakuan mengalami penurunan kecuali pada perlakuan $\mathrm{J}+$ 0.5 dosis NPK + PH $1+$ dekomposer. Kandungan unsur hara $\mathrm{P}$ dalam tanah diakhir pengamatan nilainya bervariasi, terdapat perlakuan yang mengalami peningkatan dan penurunan. 
Kandungan hara $\mathrm{P}$ tanah meningkat pada perlakuan $\mathrm{J}+0.5$ dosis NPK, $\mathrm{J}+0.5$ dosis NPK + Dek + POG + POC, $\mathrm{J}+0.5$ dosis NPK + Dek + $\mathrm{POG}+\mathrm{POC}+\mathrm{PH} 1,0.5$ dosis NPK +0.5 dosis $\mathrm{PH}$ $2, \mathrm{~J}+0.5$ dosis NPK +0.5 dosis $\mathrm{PH} 2$, dan perlakuan tanpa pupuk. Kenaikan hara $\mathrm{P}$ tanah diduga karena aplikasi pupuk hayati yang mengandung bakteri pelarut fosfat sehingga ketersediaan fosfat dalam tanah akan meningkat unttuk diserap tanamann dan adanya penambahan pupuk NPK ke dalam tanah. Kandungan hara P tanah menurun terlihat pada perlakuan 1 dosis $\mathrm{NPK}, \mathrm{J}+1$ dosis NPK, $\mathrm{J}+0.5$ dosis NPK $+\mathrm{PH} 1$, $\mathrm{J}+0.5$ dosis NPK + PH $1+$ POG, $\mathrm{J}+0.5$ dosis $\mathrm{NPK}+\mathrm{PH} 2$, dan 0.5 dosis NPK + PH 2. Penurunan hara $\mathrm{P}$ diduga karena tidak diaplikasikannya jerami, diaplikasikan jerami tetapi tidak ditambahkan dekomposer, tidak efektifnya bakteri pelarut fosfat pada pupuk hayati, dan adanya serapan hara oleh tanaman yang menyebabkan hara dalam tanah berkurang.

Tabel 2. Hasil analisa serapan hara pada jerami

\begin{tabular}{lccc}
\hline \multicolumn{1}{c}{ Perlakuan } & $\begin{array}{c}\mathrm{Kg} \mathrm{N} \mathrm{ton}^{-1} \\
\text { jerami }\end{array}$ & $\begin{array}{c}\mathrm{Kg} \mathrm{P} \mathrm{ton}^{-1} \\
\text { jerami }\end{array}$ & $\begin{array}{c}\mathrm{Kg} \mathrm{K}^{-1} \\
\text { jerami }\end{array}$ \\
\hline 1 dosis NPK & 7.8 & 1.5 & 12.0 \\
0J + 1 dosis NPK & 9.2 & 1.8 & 12.4 \\
Tanpa Pupuk & 8.4 & 1.6 & 11.9 \\
J + 0.5 dosis NPK & 8.7 & 1.6 & 12.8 \\
J + 0.5 dosis NPK + PH1 & 9.7 & 1.7 & 13.1 \\
J + 0.5 dosis NPK + PH1+ Dek & 10.5 & 1.9 & 12.6 \\
J + 0.5 dosis NPK + PH1 + POG & 9.0 & 1.6 & 12.8 \\
J + 0.5 dosis NPK + Dek+ POG + POC & 9.5 & 1.8 & 11.9 \\
J + 0.5dosis NPK + Dek + POG + POC +PH1 & 8.0 & 1.5 & 12.4 \\
J + 0.5 dosis NPK + PH 2 & 9.7 & 2.1 & 11.6 \\
0.5 dosis NPK + PH 2 & 8.6 & 1.6 & 11.3 \\
0.5 dosis NPK + 0.5 dosis PH 2 & 9.2 & 1.7 & 12.7 \\
J + 0.5 dosis NPK + 0.5 dosis PH 2 & 10.6 & 2.1 & 12.6 \\
\hline
\end{tabular}

Secara umum perlakuan pembenaman jerami, aplikasi pupuk hayati dan organik, dan reduksi 50\% pupuk NPK menghasilkan serapan hara $\mathrm{N}, \mathrm{P}$ dan $\mathrm{K}$ yang lebih besar dibandingkan perlakuan satu dosis pupuk NPK. Dengan demikian pembenaman jerami, pupuk hayati dan organik, dan pupuk NPK dikurangi hingga $50 \%$ dapat memberikan ketersediaan hara yang cukup bagi tanaman. Dalam penelitian ini diperoleh bahwa serapan jerami hara $\mathrm{N}$ berkisar $7.2-10.6 \mathrm{~kg}$ $\mathrm{N}$ ton $^{-1}$, hara $\mathrm{P} 1.5-2.1 \mathrm{~kg} \mathrm{P}$ ton $^{-1}$, dan hara $\mathrm{K}$ 11.3$13.1 \mathrm{~kg} \mathrm{~K}$ ton $^{-1}$. Hasil tersebut lebih besar dibandingkan hasil penelitian Dobermann and Fairhurst (2000) yang menyatakan bahwa jerami menyerap 6-8 kg N ton ${ }^{-1}, 0.8-1.2 \mathrm{~kg} \mathrm{P}$ ton $^{-1}$, dan hara $12-17 \mathrm{~kg} \mathrm{~K}_{\text {ton }^{-1}}$. Sedangkan untuk hara $\mathrm{K}$ hasil yang diperoleh cenderung sama kecuali pada perlakuan $\mathrm{J}+0.5$ dosis NPK + Dek + POG + POC,
Kandungan unsur hara $\mathrm{K}$ dalam tanah diakhir percobaan menunjukan adanya penurunan pada semua perlakuan. Penurunan hara K tertinggi terlihat pada perlakuan jerami +0.5 dosis NPK + $\mathrm{PH}$ 2. Hal tersebut diduga karena dekomposisi jerami belum sempurna. Penurunan hara K diduga karena serapan hara $\mathrm{K}$ tinggi pada padi sawah (seperti pada Tabel 2 dan Tabel 3) sehingga terjadi pengurasan hara $\mathrm{K}$ tanah.

Hasil analisis serapan hara dalam jerami menunjukkan bahwa hara $\mathrm{N}$ yang terserap oleh jerami pada perlakuan jerami, pupuk hayati, pupuk organik dan $50 \%$ NPK lebih besar dibandingkan perlakuan satu dosis NPK. Hal ini terlihat juga pada serapan hara $\mathrm{P}$ bahwa perlakuan jerami, pupuk hayati, pupuk organik dan $50 \%$ NPK lebih besar dibandingkan perlakuan satu dosis NPK kecuali pada perlakuan $\mathrm{J}+0.5$ dosis NPK + Dek + $\mathrm{POG}+\mathrm{POC}+\mathrm{PH} 1$. Sedangkan pada serapan hara $\mathrm{K}$ pada perlakuan jerami, pupuk hayati, pupuk organik dan reduksi $50 \%$ NPK cenderung lebih besar dibandingkan perlakuan satu dosis NPK.
$\mathrm{J}+0.5$ dosis NPK + PH 2, dan 0.5 dosis NPK + PH 2. Hal ini diduga karena dekomposisi jerami belum sempurna.

Hasil pengamatan serapan hara dalam gabah disajikan pada Tabel 3. Dobermann and Fairhurst (2000), menyatakan ketersediaan unsur hara $\mathrm{N}$ optimum apabila serapan gabah sebesar $14-16 \mathrm{~kg}$ ton $^{-1}$ gabah, terbatas pada serapan $11-13 \mathrm{~kg}$ ton $^{-1}$ gabah, dan sangat terbatas sama dengan $10 \mathrm{~kg} \mathrm{~N}$ ton $^{-1}$ gabah. Kriteria serapan unsur $\mathrm{P}$ yaitu apabila gabah mengandung $1.6 \mathrm{~kg}^{-1}$ ton $^{-1} \mathrm{P}$ tergolong sangat terbatas, $1.7-2.3 \mathrm{~kg}^{-1}$ ton $^{-1} \mathrm{P}$ tergolong terbatas, $2.4-$ $2.8 \mathrm{~kg}$ tergolong optimum, 2.9-4.8 tergolong berlebih dan > 4.9 tergolong sangat berlebih. Untuk kandungan $\mathrm{K}(\mathrm{kg})$ setiap ton gabah sebesar $<0.9$ ton menunjukkan ketersediaan hara sangat terbatas; $1-1.3$ tergolong terbatas, $1.4-1.6$ optimum, $1.7-2.7$ tergolong berlebih dan $>2.8$ 
tergolong sangat berlebih. Berdasarkan kriteria serapan hara Dobermann and Fairhurst tersebut diperoleh bahwa perlakuan pembenaman jerami, pupuk organik dan hayati, dan reduksi $50 \%$ pupuk NPK mempunyai status hara yang optimum untuk hara $\mathrm{N}$ kecuali pada perlakuan satu dosis NPK, J + 1 dosis NPK, dan 0.5 dosis NPK + PH 2, tanpa pembenaman jerami atau menggunakan jerami tetapi tidak diberikan pupuk hayati. Sedangkan status hara $\mathrm{P}$ tergolong berlebih dan status hara $\mathrm{K}$ tergolong sangat berlebih. Serapan hara N, P, dan $\mathrm{K}$ pada jerami yang cukup tinggi, maka jerami berpotensi sebagai bahan organik. Sehingga perlakuan jerami, pupuk organik dan hayati, masih dapat memenuhi kebutuhan hara tanaman walaupun pupuk NPK dikurangi hingga $50 \%$.

Tabel 3. Hasil analisis serapan hara pada gabah

\begin{tabular}{|c|c|c|c|c|c|c|}
\hline Perlakuan & $\begin{array}{c}\mathrm{Kg} \mathrm{N} \text { ton }^{-1} \\
\text { gabah }\end{array}$ & $\begin{array}{c}\text { Status } \\
\text { kecukupan } \\
\text { hara } \\
\end{array}$ & $\begin{array}{c}\mathrm{Kg} \mathrm{P}_{\text {ton }}^{-1} \\
\text { gabah }\end{array}$ & $\begin{array}{c}\text { Status } \\
\text { kecukupan } \\
\text { hara }\end{array}$ & $\begin{array}{c}\mathrm{Kg} \mathrm{K} \text { ton }^{-1} \\
\text { gabah }\end{array}$ & $\begin{array}{c}\text { Status } \\
\text { kecukupan } \\
\text { hara }\end{array}$ \\
\hline 1 dosis NPK & 13.2 & $\mathrm{~T}$ & 3.0 & $\mathrm{~B}$ & 8.4 & SB \\
\hline $\mathrm{J}+1$ dosis NPK & 13.4 & $\mathrm{~T}$ & 3.4 & $\mathrm{~B}$ & 8.7 & SB \\
\hline Tanpa Pupuk & 14.1 & $\mathrm{O}$ & 3.6 & $\mathrm{~B}$ & 8.6 & SB \\
\hline $\mathrm{J}+0.5$ dosis NPK & 14.6 & $\mathrm{O}$ & 3.8 & $\mathrm{~B}$ & 8.8 & SB \\
\hline $\mathrm{J}+0.5$ dosis NPK $+\mathrm{PH} 1$ & 17.4 & $\mathrm{O}$ & 3.9 & $\mathrm{~B}$ & 8.9 & SB \\
\hline $\mathrm{J}+0.5$ dosis NPK + PH1 + Dek & 14.5 & $\mathrm{O}$ & 3.8 & $\mathrm{~B}$ & 9.0 & SB \\
\hline $\mathrm{J}+0.5$ dosis NPK + PH1 + POG & 16.2 & $\mathrm{O}$ & 4.1 & B & 9.2 & SB \\
\hline $\mathrm{J}+0.5$ dosis NPK +Dek+POG+ POC & 16.4 & $\mathrm{O}$ & 3.9 & B & 9.4 & SB \\
\hline $\begin{array}{l}\mathrm{J}+0.5 \text { dosis NPK }+ \text { Dek }+ \text { POG }+ \text { POC } \\
+\mathrm{PH} 1\end{array}$ & 15.3 & $\mathrm{O}$ & 3.6 & B & 9.3 & SB \\
\hline $\mathrm{J}+0.5$ dosis $\mathrm{NPK}+\mathrm{PH} 2$ & 16.4 & $\mathrm{O}$ & 4.0 & $\mathrm{~B}$ & 9.6 & SB \\
\hline 0.5 dosis NPK + PH 2 & 13.4 & $\mathrm{~T}$ & 3.6 & B & 9.6 & SB \\
\hline 0.5 dosis NPK +0.5 dosis $\mathrm{PH} 2$ & 15.4 & $\mathrm{O}$ & 3.8 & $\mathrm{~B}$ & 9.5 & SB \\
\hline $\mathrm{J}+0.5$ dosis NPK +0.5 dosis $\mathrm{PH} 2$ & 16.4 & $\mathrm{O}$ & 3.9 & $\mathrm{~B}$ & 9.6 & SB \\
\hline
\end{tabular}

Sumber:Status kecukupan hara Dobermann and Fairhurst (2000)

Keterangan: $\mathrm{T}=$ Terbatas; $\mathrm{O}=$ Optimum; $\mathrm{B}=$ Berlebih; $\mathrm{SB}=$ sangat berlebih

Pengamatan populasi mikroba tanah dilakukan untuk spesies Azotobater sp., Azospirillium $s p$ dan Thiobacillus sp. Hasil pengamatan secara rinci disajikan pada Tabel 4. Azospirillum merupakan bakteri penambat $\mathrm{N}_{2}$ dan pemacu tumbuh tanaman yang hidup bebas mengkolonisasi permukaan luar dan dalam akar tanaman padi, jagung, tebu, dan rerumputan lainya (Saraswati et al., 2004). Selain mampu menambat nitrogen, Azotobacter juga berperan sebagai agen peningkat pertumbuhan tanaman melalui produksi fitohormon yang dapat dimanfaatkan oleh tanaman (Hindersah et al., 2004).

Tabel 4. Hasil analisis mikroba tanah setelah percobaan

\begin{tabular}{llll}
\hline \multicolumn{1}{c}{ Perlakuan } & $\begin{array}{c}\text { Azospirillium } \\
(\mathrm{MPN} / \mathrm{g})\end{array}$ & $\begin{array}{c}\text { Azotobater } \\
(\mathrm{CFU} / \mathrm{g})\end{array}$ & $\begin{array}{c}\text { Thiobacillus } \\
(\mathrm{CFU} / \mathrm{g})\end{array}$ \\
\hline 1 dosis NPK & $3.5 \times 10^{2}$ & $2.1 \times 10^{8}$ & $5.0 \times 10^{3}$ \\
$\mathrm{~J}+1$ dosis NPK & 74 & $6.2 \times 10^{7}$ & $3.6 \times 10^{3}$ \\
Tanpa Pupuk & $1.1 \times 10^{2}$ & $1.0 \times 10^{8}$ & $3.1 \times 10^{4}$ \\
$\mathrm{~J}+0.5$ dosis NPK & $2.3 \times 10^{5}$ & $1.7 \times 10^{8}$ & $3.0 \times 10^{4}$ \\
$\mathrm{~J}+0.5$ dosis NPK + PH 1 & $1.5 \times 10^{6}$ & $1.5 \times 10^{8}$ & $5.4 \times 10^{3}$ \\
$\mathrm{~J}+0.5$ dosis NPK + PH 1 + Dek & 74 & $5.0 \times 10^{5}$ & $\mathrm{ttd}$ \\
$\mathrm{J}+0.5$ dosis NPK + PH 1 + POG & $2.0 \times 10^{2}$ & $4.2 \times 10^{7}$ & $3.9 \times 10^{4}$ \\
$\mathrm{~J}+0.5$ dosis NPK + Dek + POG + POC & $1.5 \times 10^{4}$ & $9.7 \times 10^{7}$ & $2.8 \times 10^{4}$ \\
$\mathrm{~J}+0.5$ dosis NPK + Dek + POG + POC +PH1 & $1.5 \times 10^{4}$ & $1.2 \times 10^{8}$ & $6.4 \times 10^{4}$ \\
$\mathrm{~J}+0.5$ dosis NPK + PH 2 & $1.5 \times 10^{3}$ & $7.0 \times 10^{7}$ & $8.1 \times 10^{4}$ \\
0.5 dosis NPK + PH 2 & $1.1 \times 10^{2}$ & $7.3 \times 10^{6}$ & $4.7 \times 10^{5}$ \\
0.5 dosis NPK + 0.5 dosis PH 2 & ttd & $5.7 \times 10^{7}$ & $4.2 \times 10^{4}$ \\
$\mathrm{~J}+0.5$ dosis NPK + 0.5 dosis PH 2 & $2.0 \times 10^{2}$ & $2.6 \times 10^{8}$ & $5.4 \times 10^{4}$ \\
\hline
\end{tabular}

Keterangan: $\operatorname{ttd}=$ tidak terdeteksi 
Kandungan Azospirillium sp. pada pelakuan $\mathrm{J}+0.5$ dosis NPK, $\mathrm{J}+0.5$ dosis NPK + $\mathrm{PH} 1, \mathrm{~J}+0.5$ dosis NPK + Dek + POG + POC, $\mathrm{J}+$ 0.5 dosis NPK + Dek + POG + POC +PH 1, J + 0.5 dosis NPK + PH 2 lebih besar dibandingkan perlakuan satu dosis NPK. Hal ini menunjukkan bahwa pembenaman jerami, pupuk hayati dan dekomposer mampu meningkatkan kandungan Azospirillium sp. di dalam tanah. Kandungan Azotobater sp pada perlakuan $\mathrm{J}+0.5$ dosis NPK + 0.5 dosis PH 2 lebih besar dibandingkan perlakuan satu dosis NPK. Perlakuan pembenaman jerami, pupuk organik dan hayati, reduksi $50 \%$ pupuk NPK cenderung mempunyai kandungan Thiobacillus sp. yang lebih besar dibandingkan perlakuan satu dosis pupuk NPK kecuali pada perlakuan $\mathrm{J}+1$ dosis NPK dan perlakuan $\mathrm{J}+0.5$ dosis NPK + PH1+ Dekomposer yang tidak terdeteksi. Secara umum perlakuan dengan jerami, pupuk hayati dan pupuk organik, dan reduksi $50 \%$ pupuk NPK mampu meningkatkan kandungan Azospirillum sp., Azotobater sp. dan Thiobacillus sp. dibandingkan dengan perlakuan satu dosis pupuk NPK. Hal ini diduga karena meningkatnya bahan organik tanah mampu mendorong pertumbuhan populasi mikroba tanah. Azospirillum sp. dan Azotobater sp. diketahui berperan dalam pengikatan nitrogen bebas dari udara, sehingga akan meningkatkan ketersediaan nitrogen dalam tanah untuk diserap tanaman. Dengan demikian aplikasi pupuk hayati diduga dapat berkontribusi dalam penyediaan unsur hara sehingga dosis pupuk NPK dapat dikurangi.

\section{Komponen Hasil dan Hasil}

Peubah komponen hasil dan hasil yang diamati meliputi jumlah anakan produktif, hasil gabah/tanaman, dan hasil gabah/ha. Hasil pengamatan secara rinci disajikan pada Tabel 5. Pengamatan jumlah anakan produktif menunjukkan bahwa perlakuan pembenaman jerami, pupuk hayati dan organik, dan reduksi pupuk NPK $50 \%$ memberikan jumlah anakan produktif yang lebih rendah dibandingkan dengan perlakuan satu dosis pupuk NPK. Hal ini menunjukkan bahwa hara $\mathrm{N}, \mathrm{P}$, dan $\mathrm{K}$ sangat diperlukan dalam pertumbuhan anakan. Unsur $\mathrm{P}$ berperan dalam meningkatkan jumlah anakan padi sawah, perkembangan akar awal pembungaan dan pemasakan (terutama di mana suhu rendah), unsur $\mathrm{K}$ meningkatkan jumlah gabah per malai, persentase gabah isi, dan bobot 1000 butir, meningkatkan toleransi tanaman padi terhadap kondisi iklim yang merugikan dan serangan hama penyakit (Dobermann and Fairhurst, 2000).

Tabel 5. Hasil pengamatan jumlah anakan produktif, hasil gabah per rumpun dan hasil gabah per ha

\begin{tabular}{lccc}
\hline \multicolumn{1}{c}{ Perlakuan } & $\begin{array}{c}\text { Jumlah Anakan } \\
\text { Produktif }\end{array}$ & $\begin{array}{c}\text { Hasil Gabah } \\
\text { Kering/rumpun }(\mathrm{g})\end{array}$ & $\begin{array}{c}\text { Hasil GKG/ha } \\
(\mathrm{kg})\end{array}$ \\
\hline 1 dosis NPK & 28.5 & 890.7 & 14216 \\
J + 1 dosis NPK & 25.5 & 1060.3 & 14141 \\
Tanpa Pupuk & 24.6 & 886.7 & 15082 \\
J + 0.5 dosis NPK & 23.3 & 894.5 & 15076 \\
J + 0.5 dosis NPK + PH 1 & 24.3 & 833.4 & 13591 \\
J + 0.5 dosis NPK + PH 1+ Dek & 24.5 & 890.3 & 15964 \\
J + 0.5 dosis NPK + PH 1 + POG & 24.4 & 923.1 & 14542 \\
J + 0.5 dosis NPK + Dek + POG + POC & 23.5 & 954.4 & 16635 \\
J + 0.5dosis NPK + Dek + POG + POC +PH1 & 24.5 & 878.2 & 16225 \\
J + 0.5 dosis NPK + PH 2 & 27.0 & 928.0 & 18116 \\
0.5 dosis NPK + PH 2 & 25.4 & 923.3 & 16143 \\
0.5 dosis NPK + 0.5 dosis PH 2 & 24.7 & 1003.0 & $18744 *$ \\
J + 0.5 dosis NPK + 0.5 dosis PH 2 & $22.9 *$ & 912.6 & 15268 \\
\hline Ken
\end{tabular}

Keterangan: Nilai pada kolom yang diikuti $(*)$ berbeda nyata dengan perlakuan 1 dosis NPK berdasarkan uji t-dunnett pada taraf $5 \%$

Perlakuan pembenaman jerami, pupuk organik dan hayati, dan reduksi $50 \%$ dosis pupuk NPK menghasilkan bobot gabah kering/tanaman yang tidak berbeda dibandingkan satu dosis pupuk NPK. Hal ini menunjukkan bahwa pembenaman jerami, aplikasi pupuk organik dan hayati, dan reduksi $50 \%$ pupuk NPK mampu menyediakan hara yang tidak berbeda dengan perlakuan satu dosis NPK. Perlakuan pembenaman jerami, pupuk organik dan hayati, dan reduksi $50 \%$ dosis pupuk NPK cenderung menghasilkan bobot gabah kering/tanaman yang lebih tinggi dibandingkan perlakuan satu dosis NPK.

Pengamatan hasil gabah kering giling (GKG) berdasarkan komponen hasil menunjukkan bahwa perlakuan 0.5 dosis NPK +0.5 dosis PH 2 menghasilkan gabah kering giling yang nyata lebih tinggi dibandingkan perlakuan satu dosis pupuk NPK. Secara umum perlakuan pembenaman jerami, pupuk organik dan hayati, dan reduksi $50 \%$ pupuk NPK cenderung menghasilkan gabah kering giling yang lebih 
tinggi dibandingkan perlakuan satu dosis NPK. Hal ini menunjukkan perlakuan dengan perlakuan pembenaman jerami, pupuk organik dan hayati, dan reduksi $50 \%$ pupuk NPK mampu menyediakan unsur hara yang cukup bagi tanaman sehingga tanaman mampu berproduksi tinggi.

\section{KESIMPULAN}

Pembenaman jerami dengan pemberian pupuk hayati dan atau pupuk organik serta reduksi dosis pupuk NPK hingga $50 \%$ mampu meningkatkan ketersediaan hara dalam tanah, meningkatkan populasi mikroba tanah serta mampu memberikan hasil gabah/tanaman maupun hasil gabah/ha yang tidak berbeda dengan perlakuan dosis pupuk NPK penuh. Dengan demikian pembenaman jerami dan penggunaan pupuk hayati atau pupuk organik dapat mengurangi penggunaan pupuk NPK hingga $50 \%$ tanpa mengurangi hasil

\section{DAFTAR PUSTAKA}

[BPS] Badan Pusat Statistik. 2010. Produksi Tanaman Pangan [Internet]. [Diunduh 2010 Sept 10] . Tersedia pada http://www.bps.go.id .

Basyir, A., Suyamto. 1996. Penelitian padi untuk mendukung pelestarian swasembada pangan. Apresiasi Hasil Penelitian Balai Penelitian Padi [Prosiding Seminar]. Bogor (ID): Badan Litbang Pertanian.

Dobermann, A., Fairhurst, T. 2000. Rice : Nutrient Disorders \& Nutrient Management. Canada (USA) : Potash \& Potash Institute/Potash \& Potash Institute of Canada.
Eagle, A.J., Bird, A.j., Horwath, W.R., Linguist, B.A., Brouder, S.M., Hill, J.E.,Van Kessel, C. 2000. Rice yield and nutrigen utilization efficiency under alternative straw management practice. J. Agron. 92:1096-1103.

Reginawanti, H., Tualar, S. 2004. Potensi Rizobakteri Azotobacter dalam Meningkatkan Kesehatan Tanah. Jurnal Natur Indonesia. 5(2): 127-133 (2004).

Las, I., Makarim, A.K., Sumarno, Purba, S., Mardikarini, M., Kartaatmadja, M. 1999. Pola IP Padi-300, Konsepsi Dan Prospek Implementasi System Usaha Pertanian Berbasis Sumberdaya. Bogor (ID) : Badan Litbang Pertanian.

Rahmawati, Nini. 2005. Pemanfaatan Biofertilizer pada Pertanian Organik. Medan (ID) : USU Repository.

Saraswati, R., Prihatini, T., Hastuti, R.D. 2004. Teknologi Pupuk Mikroba Untuk Meningkatkan Efisiensi Pemupukan dan Keberlanjutan sistem Produksi Padi Sawah. Dalam Agus, F., A. Adimihardja, A. A. Fagi dan W. Hartati (ed.). Tanah Sawah dan Teknologi Pengelolaannya. Pusat Penelitian dan Pengembangan Tanah dan Agroklimat. Jakarta (ID) : Departemen Pertanian.

Widati, S., Santosa, E., Prihatin, T. 2000. Pengaruh inokulan dalam berbagai cara peberian jerami terhadap sifat kimia tanah dan hasil padi sawah. Nasional Reorientasi Pendayagunaan Sumberdaya Tanah [Prosiding Seminar]. Bogor (ID) : Pusat Penelitian dan Pengembangan Tanah Dan Agroklimat. 